\title{
JURNALKU
}

Volume 1 No. 1, Maret 2021

\section{ASPEK PAJAK PENGHASILAN OTORITAS JASA KEUANGAN}

\author{
Ania Zahra Shofira' ${ }^{1)}$, Wahyu Widodo Rodhiawan²) \\ 1) aniazhrsh@gmail.com, Politeknik Keuangan Negara STAN \\ 2) rdw.wahyu@gmail.com, Direktorat Jenderal Pajak
}

\begin{abstract}
The purpose of this research is to examine the subjective requirements of the Financial Services Authority (OJK), examine the remaining benefits of OJK levies as tax objects, and aspects of income tax at OJK. The research was conducted with descriptive qualitative method. The results of the study indicate that OJK is included in the subject of corporate income tax, because it does not meet the accumulative requirements in Article 2 paragraph (3) letter $b$ of the Income Tax Law (UU PPh) regarding entities that are excluded from domestic corporate tax subjects. The remaining benefits from levies from financial institutions are the object of the OJK income tax, because the surplus is an additional economic capability for the OJK. OJK has met the subjective and objective requirements in accordance with the Income Tax Law Article 2 paragraph (1) of the Law on General Provisions and Tax Procedures (UU KUP), so that tax obligations arise in the form of income tax payments and reporting of Notification Letter (SPT).
\end{abstract}

Keywords : Financial Services Authority, Income Tax, Tax Object, Tax Subject

\begin{abstract}
Abstrak
Tujuan penelitian adalah meneliti syarat subjektif Otoritas Jasa Keuangan (OJK), meneliti sisa manfaat pungutan OJK sebagai objek pajak, dan aspek pajak penghasilan pada OJK. Penelitian dilakukan dengan metode kualitatif deskriptif. Hasil penelitian menunjukkan bahwa OJK termasuk ke dalam subjek pajak penghasilan berbentuk badan, karena tidak memenuhi persyaratan akumulatif dalam Pasal 2 ayat (3) huruf b Undang-Undang Pajak Penghasilan (UU PPh) mengenai badan yang dikecualikan dari subjek pajak badan dalam negeri. Sisa manfaat pungutan dari lembaga keuangan merupakan objek pajak penghasilan OJK, karena surplus tersebut merupakan tambahan kemampuan ekonomis bagi OJK. OJK telah memenuhi persyaratan subjektif dan objektif sesuai dengan UU PPh Pasal 2 ayat (1) UU Ketentuan Umum dan Tata Cara Perpajakan (UU KUP), sehingga timbul kewajiban perpajakan berupa pembayaran Pajak Penghasilan dan pelaporan Surat Pemberitahuan (SPT).
\end{abstract}

Kata kunci : Objek Pajak, Otoritas Jasa Keuangan, Pajak penghasilan, Subjek Pajak

\section{PENDAHULUAN}

Pemerintah semakin gencar melaksanakan program-program pembangunan di berbagai daerah demi melakukan pemerataan kesejahteraan masyarakat di berbagai bidang. Programprogram tersebut selaras dengan Rencana Pembangunan Jangka Menengah yang disusun oleh Presiden Republik Indonesia, Joko Widodo, yang tertuang dalam sembilan agenda prioritas presiden atau yang biasa disebut dengan Nawacita. Tentunya, dalam rangka pembiayaan pelaksanaan program-program tersebut dibutuhkan sumber pendanaan. Salah satu sumber pendapatan negara terbesar adalah sektor perpajakan, tepatnya adalah PPh NonMigas. Per 31 Oktober 2018, pendapatan negara telah mencapai Rp1.483,76 trilun, yang mana PPh NonMigas memiliki presentase sebesar 65,96\% dari total APBN, tepatnya sebesar Rp538,91 triliun ${ }^{1}$. Jumlah penerimaan yang tinggi tersebut tidak terlepas dari peranan Wajib Pajak. Wajib Pajak adalah orang pribadi atau badan, meliputi pembayar pajak, pemotong pajak, dan pemungut pajak yang mempunyai hak dan kewajiban perpajakan sesuai dengan ketentuan peraturan perundang-undangan perpajakan. Kata Badan dalam pengertian Wajib Pajak adalah sekumpulan orang dan/atau modal yang merupakan kesatuan baik yang melakukan usaha maupun yang tidak melakukan usaha, meliputi berbagai macam bentuk yang salah satunya adalah lembaga.

Otoritas Jasa Keuangan (selanjutnya disingkat OJK) merupakan lembaga yang independen dan bebas dari campur tangan pihak lain, yang mempunyai fungsi, tugas, dan wewenang pengaturan, pengawasan, pemeriksaan, dan penyidikan. Sesuai dengan pengertian

\footnotetext{
1 Kementerian Keuangan. APBN Kita edisi November 2018. https://www.kemenkeu.go.id/media/11095/apbn-kita-edisi-
} november-2018.pdf. 


\section{JURNALKU}

Volume 1 No. 1, Maret 2021

OJK sebagai lembaga, maka OJK termasuk kedalam pengertian Badan menurut UU No. 36 Tahun 2008 tentang Pajak Penghasilan. Objek pajak dalam penghasilan OJK adalah sisa pemanfaatan pungutan industri keuangan sebesar 5\%. Namun, dalam pelaksanaannya terdapat inkonsistensi status OJK dari segi subjek pajak badan dan objek pajak penghasilannya.

Pada tahun 2015, OJK meminta kepada Kementerian Keuangan agar dikecualikan dari subjek pajak dengan dasar bahwa pungutan yang dilakukan oleh OJK memiliki kedudukan yang sama dengan pajak yang dipungut oleh Direktorat Jenderal Pajak (DJP). Diketahui pula pada saat itu OJK memiliki utang pajak sebesar Rp1,3 Triliun, yang menurut OJK utang pajak tersebut termasuk utang pajak tahun 2014, 2015 dan rencana anggaran utang pajak 2016 termasuk denda perpajakannya. ${ }^{3}$ Namun, permohonan tersebut ditolak oleh Kementerian Keuangan melalui surat yang dijawab oleh Menteri Keuangan pada saat itu, Bambang Brodjonegoro. Dalam surat tersebut dijelaskan bahwa OJK adalah termasuk kedalam pengertian Badan dan tidak memenuhi kriteria sebagai badan pemerintah yang dikecualikan dari subjek pajak. ${ }^{4}$ Sehingga, pada awal 2016 OJK menyatakan telah melunasi kewajiban perpajakannya selama $2014 .^{5}$

Tidak selesai di situ, pada tahun 2018 ini, tepatnya bulan Oktober, BPK mendapatkan temuan mengenai utang pajak yang masih harus dibayar oleh OJK per 31 Desember 2017, yaitu sebesar Rp901,10 miliar dan belum dilunasi. ${ }^{6}$ OJK pun memberikan tanggapan bahwa angka tersebut merupakan akumulasi utang pajak tahun 2015, 2016, dan 2017, sedangkan OJK telah melakukan pembayaran atas kewajiban perpajakannya untuk tahun 2014 dan 2015 sebesar Rp836,72 miliar dan berencana membahas skema perpajakannya dengan Direktorat Jenderal Pajak. $^{7}$

Maka, dari kasus tersebut dapat ditarik kesimpulan bahwa terdapat ketidakjelasan mengenai status perpajakan OJK sehingga menyebabkan OJK tidak dapat melakukan kewajiban perpajakannya secara tepat. Tujuan penelitian adalah meneliti syarat subjektif Otoritas Jasa Keuangan (OJK), meneliti sisa manfaat pungutan OJK sebagai objek pajak, dan aspek pajak penghasilan pada OJK.

\section{KAJIAN TEORI Pajak}

Pengertian Pajak menurut Prof. Dr. Rochmat Soemitro, S.H. dalam Mardiasmo (2011) adalah iuran rakyat kepada kas negara berdasarkan undang-undang (yang dapat dipaksakan) dengan tidak mendapat jasa timbal (kontra Prestasi) yang langsung dapat ditunjukkan dan yang digunakan untuk membayar pengeluaran umum. Sedangkan menurut P. J. A. Adriani dalam Waluyo (2011), yang dimaksud dengan pajak adalah iuran kepada negara (yang dapat dipaksakan yang terutang) oleh yang wajib membayarnya menurut peraturan-peraturan, dengan tidak mendapat prestasi kembali, yang langsung dapat ditunjuk, dan yang gunanya adalah untuk membiayai pengeluaran-pengeluaran umum berhubungan dengan tugas negara yang

\footnotetext{
2 Kontan. Terkait Utang Pajak Dirjen Pajak, OJK Pasti Akan Melaksanakan Rekomendasi BPK. https://nasional.kontan.co.id/news/terkait-utang-pajak-ditjen-pajak-ojk-pasti-akan-melaksanakan-rekomendasi-bpk

3 Okezone. (2015, Desember 14). Dijadikan Subjek Pajak, OJK Layangkan Surat ke Kemenkeu. https://economy.okezone.com/read/2015/12/14/20/1267451/dijadikan-subjek-pajak-ojk-layangkan-surat-ke-menkeu

4 CNN. (2016, Januari 1). Permohonan Ditolak, Ditjen Pajak Tetap Tagih Rp1,3 $T$ dari OJK. https://www.cnnindonesia.com/ekonomi/20160106133458-78-102574/permohonan-ditolak-ditjen-pajak-tetap-tagih-rp13-tdari-ojk?

5 CNN. (2016, Januari 8). Mengaku Tetap Subjek Pajak, OJK Lunasi Utang Rp1,3 Triliun. https://www.cnnindonesia.com/ekonomi/20160108175207-78-103081/mengaku-tetap-subjek-pajak-ojk-lunasi-utang-rp13triliun

6 Detik Finance. (2018, Oktober 2). BPK: OJK Harus Bayar Utang Pajak Rp 901 Miliar. Detik Finance: https://finance.detik.com/berita-ekonomi-bisnis/d-4238549/bpk-ojk-harus-bayar-utang-pajak-rp-901-miliar

${ }^{7}$ Kata Data. (2018, Oktober 3). Tanggapi BPK, OJK Bahas Skema Baru PPh Badan dengan Ditjen Pajak. Kata Data: https://katadata.co.id/berita/2018/10/03/tanggapi-bpk-ojk-bahas-skema-baru-pph-badan-dengan-ditjen-pajak.
} 


\section{JURNALKU}

Volume 1 No. 1, Maret 2021

menyelenggarakan pemerintahan Sommerfeld Ray M., Anderson Herschel M., dan Brock Horace R. dalam Zain (2008) memberikan pendapat bahwa pajak adalah suatu pengalihan sumber dari sektor swasta ke sektor pemerintah, bukan akibat pelanggaran hukum, namun wajib dilaksanakan berdasarkan ketentuan yang diterapkan lebih dahulu tanpa mendapat imbalan yang langsung dan proporsional agar pemerintah dapat melaksanakan tugas-tugasnya untuk menjalankan pemerintahan. Pajak penghasilan juga merupakan pajak subjektif, di mana menurut Brotodihardjo (2003, dikutip dalam Wijaya \& Utamawati, 2018) adalah pajak yang memerhatikan keadaan wajib pajak, yaitu untuk menetapkan pajaknya harus ditemukan alasan-alasan yang objektif yang berhubungan erat dengan keadaan materialnya, yaitu yang disebut dengan gaya pikul (ability to-pay).

Selain itu, pada Undang Undang Nomor 16 Tahun 2009 tentang Ketentuan Umum dan Tata Cara Perpajakan (UU KUP) dijelaskan juga bahwa pajak adalah kontribusi wajib kepada negara yang terutang oleh orang pribadi atau badan yang bersifat memaksa berdasarkan Undang-Undang, dengan tidak mendapat imbalan secara langsung dan digunakan untuk keperluan negara bagi sebesar-besarnya kemakmuran rakyat.

\section{Penghasilan}

Pengertian penghasilan dalam Kamus Besar Bahasa Indonesia adalah proses, cara, dan perbuatan yang menghasilkan. Selain pengertian tersebut, dalam KBBI dijelaskan bahwa penghasilan bersinonim dengan pendapatan dan perolehan.

\section{Pajak Penghasilan}

Menurut Rahayu (2010), pajak penghasilan adalah pajak yang terhutang sehubungan dengan pekerjaan, jasa, dan kegiatan yang wajib dipotong dan disetorkan oleh pemberi kerja. Jadi PPh merupakan pajak atas penghasilan berupa upah, gaji, honorarium, tunjangan, dan pembayaran lain dengan namadan dalam bentuk apapun sehubungan dengan pekerjaan atau jabatan, jasa, dan kegiatan yang dilakukan oleh orang pribadi subjek pajak dalam negeri. Judisseno (1997) juga menyatakan bahwa pajak penghasilan adalah suatu pungutan resmi yang ditujukan kepada masyarakat yang berpenghasilan atau atas penghasilan yang diterima atau diperoleh dalam tahun pajak untuk kepentingan negara dan masyarakat dalam hidup berbangsa dan bernegara sebagai suatu kewajiban yang harus dilaksanakannya.

\section{Subjek Pajak}

Sebagaimana telah diatur dalam Undang-Undang Nomor 7 Tahun 1983 sebagaimana telah diubah terakhir dengan Undang-Undang Nomor 36 Tahun 2008 tentang Pajak Penghasilan pasal 2 ayat (1), yang termasuk subjek pajak adalah (1) orang pribadi; (2) warisan yang belum terbagi sebagai satu kesatuan menggantikan yang berhak; (3) badan; dan (4) bentuk usaha tetap. Selain itu, subjek pajak penghasilan juga terbagi menjadi dua, yaitu subjek pajak dalam negeri (SPDN) dan subjek pajak luar negeri (SPLN).

\section{Badan Pemerintah yang Tidak Dikenakan Pajak Penghasilan}

Dalam Undang-Undang Nomor 36 Tahun 2008 tentang Pajak Penghasilan pasal 2 ayat (3) huruf b dijelaskan bahwa kriteria unit tertentu dari badan pemerintah yang tidak dikenakan pajak penghasilan adalah (1) Pembentukannya berdasarkan ketentuan peraturan perundangundangan; (2) Pembiayaannya bersumber dari Anggaran Pendapatan dan Belanja Negara (APBN) atau Anggaran Pendapatan dan Belanja Daerah (APBD), (3) Penerimaannya dimasukkan dalam anggaran Pemerintah Pusat atau Pemerintah Daerah, dan (4) Pembukuannya diperiksa oleh aparat pengawasan fungsional negara.

\section{METODE}

Penelitian dilakukan dengan menggunakan metode kualitatif deskriptif. Sugiyono (2016, dikutip dalam Wijaya, 2017) menjelaskan bahwa kualitatif deskriptif dapat digunakan untuk meneliti pada kondisi obyek yang alamiah, teknik pengumpulan datanya gabungan, 


\section{JURNALKU}

Volume 1 No. 1, Maret 2021

analisis data bersifat induktif, dan hasilnya generalisasi. Moleong (2010, dikutip dalam Wijaya \& Safira, 2021) menyatakan bahwa penelitian kualitatif bermaksud untuk memahami fenomena tentang apa yang dialami oleh subjek penelitian misalnya perilaku, persepsi, motivasi, tindakan, dan lain-lain secara holisticdan dengan cara deskripsi dalam bentuk kata-kata dan bahasa, pada suatu konteks khusus yang alamiah dan dengan memanfaatkan berbagai metode alamiah. Pengumpulan data dilakukan dengan menggunakan data primer dan data sekunder. Data primer diperoleh dari wawancara dengan narasumber dari akademisi Politeknik Keuangan Negara STAN yang sudah mempunyai pengalaman dan keahlian di bidang perpajakan. Menurut Basrowi \& Suwandi (2009, dalam Wijaya \& Nirvana, 2021), dalam penelitian kualitatif dikenal berbagai model wawancara, salah satunya adalah wawancara tidak terstruktur. Model wawancara yang digunakan dalam penelitian yang dilakukan adalah model wawancara tidak terstruktur. Sedangkan data sekunder diperoleh dari laporan keuangan OJK, ketentuan perpajakan, dan berbagai media online sebagai bahan untuk menunjukkan fenomena penelitian.

\section{HASIL DAN PEMBAHASAN \\ Data dan Fakta Otoritas Jasa Keuangan}

Berdasarkan Undang Undang No. 21 tahun 2011, Otoritas Jasa Keuangan (OJK) adalah lembaga yang independen dan bebas dari campur tangan pihak lain, yang mempunyai fungsi, tugas, dan wewenang pengaturan, pengawasan, pemeriksaan,dan penyidikan. OJK mempunyai visi untuk menjadi lembaga pengawas industri jasa keuangan yang terpercaya, melindungi kepentingan konsumen dan masyarakat dan mampu mewujudkan industri jasa keuangan menjadi pilar perekonomian nasional yang berdaya saing global serta dapat memajukan kesejahteraan umum. Sedangkan misi Otoritas Jasa Keuangan yaitu mewujudkan terselenggaranya seluruh kegiatan di dalam sektor jasa keuangan secara teratur, adil, transparan, dan akuntabel, mewujudkan sistem keuangan yang tumbuh secara berkelanjutan dan stabil, serta melindungi kepentingan konsumen dan masyarakat.

Untuk membiayai kegiatan administratif, pengadaan aset, operasional dan kegiatan pendukung lainnya, Otoritas Jasa Keuangan mengenakan pungutan. Pungutan yang dimaksud yaitu sejumlah uang yang dibayarkan oleh pihak yang berkegiatan di sektor jasa keuangan dan bersifat wajib. Sektor jasa keuangan tersebut meliputi perbankan, perasuransian, pasar modal, lembaga pembiayaan, dana pensiun, dan lembaga jasa keuangan lainnya. OJK sebelumnya mendapatkan anggaran dari APBN. Kemudian sejak tahun 2016 pendapatan OJK hanya bersumber dari pungutan tersebut.

Pungutan OJK terbagi menjadi dua kategori yang meliputi biaya perizinan, persetujuan, pendaftaran dan penelaahan atas rencana aksi korporasi dan biaya tahunan dalam rangka pengaturan, pengawasan, pemeriksaan, dan penelitian. Apabila pungutan yang diterima OJK sebagai pendapatan melebihi jumlah belanja pada tahun anggaran berikutnya, maka kelebihan tersebut disetorkan ke kas negara dengan berkoordinasi dengan Menteri Keuangan. Dasar hukum mengenai pungutan OJK dapat dilihat dalam Peraturan Pemerintah Nomor 11 Tahun 2014 tentang Pungutan oleh OJK. Berdasarkan Undang-Undang Nomor 21 Tahun 2011 tentang OJK, dinyatakan bahwa OJK wajib menyusun laporan keuangan dan laporan kegiatan. Laporan keuangan tersebut terdiri dari laporan keuangan semesteran dan tahunan. Publik dapat mengakses laporan keuangan tersebut pada ojk.go.id yang merupakan laman resmi OJK.

Dari laporan keuangan tersebut, diketahui bahwa OJK terdaftar sebagai wajib pajak Kantor Pelayanan Pajak (KPP) Pratama Jakarta Sawah Besar Dua. Penelitian juga mendapatkan data laporan aktivitas terkait pendapatan dan beban, jumlah aset pajak tangguhan (deffered tax asset), serta utang pajak badan OJK. Dari tabel-tabel tersebut, dapat disimpulkan bahwa OJK telah berusaha untuk melakukan kewajiban perpajakannya. 


\section{JURNALKU}

Volume 1 No. 1, Maret 2021

\section{Pembahasan}

\section{Pengidentifikasian Otoritas Jasa Keuangan sebagai subjek pajak penghasilan.}

Pada Undang-Undang Nomor 36 Tahun 2008 tentang Pajak Penghasilan, dijelaskan bahwa orang pribadi, warisan yang belum terbagi, badan, dan bentuk usaha tetap termasuk kedalam subjek pajak. Lebih lanjut lagi, yang dapat dikategorikan kedalam pengertian badan dalam undang-undang tersebut adalah sekumpulan orang atau modal, baik menjalankan usaha maupun yang tidak. Disebutkan juga bahwa lembaga termasuk kedalam pengertian badan. Otoritas Jasa Keuangan sebagaimana dalam Undang-Undang Nomor 21 Tahun 2011 termasuk kedalam pengertian badan karena pada pasal 1 ayat (1) diterangkan bahwa OJK merupakan sebuah lembaga independen yang bebas dari campur tangan pihak lain. Selain itu, OJK juga merupakan lembaga yang bertujuan untuk mengawasi lembaga-lembaga yang bergerak dalam sektor jasa keuangan, sehingga dapat diartikan bahwa OJK bukan lembaga yang mengedepankan keuntungan. Kemudian, terdapat pengecualian yang terdapat dalam subjek pajak badan dalam negeri yang tertuang dalam pasal 2 ayat (3) huruf b. Pengecualian tersebut diperuntukan bagi badan pemerintah berupa empat kriteria yang bersifat kumulatif, artinya keempat kriteria tersebut harus seluruhnya terpenuhi.

Kriteria pertama adalah pembentukan badan pemerintah tersebut harus berdasarkan ketentuan peraturan perundang-undangan. OJK didirikan pada tahun 2011. Pendirian OJK berdasarkan Undang-Undang Nomor 21 Tahun 2011 tentang Otoritas Jasa Keuangan. Hal ini membuktikan bahwa kriteria pertama terpenuhi oleh OJK.

Kemudian kriteria kedua adalah sumber pembiayaannya merupakan Anggaran Pendapatan dan Belanja Negara (APBN) atau Anggaran Pendapatan dan Belanja Daerah (APBD). Pada UU OJK Pasal 34, diterangkan bahwa sumber anggaran OJK adalah APBN dan/atau pungutan dari pihak yang berkegiatan di sektor jasa keuangan. Namun, berdasarkan laporan keuangan OJK tahun 2016 dan 2017, ditemukan keterangan yang mengemukakan bahwa anggaran OJK hanya bersumber dari pungutan sejak tahun 2016. Keterangan tersebut menandakan bahwa OJK telah memiliki penghasilan sendiri dan tidak lagi dibiayai oleh APBN, sehingga membuat kriteria kedua tidak terpenuhi.

Selanjutnya, kriteria ketiga adalah penerimaannya dimasukkan kedalam anggaran Pemerintah Pusat atau pemerintah daerah. Apabila pungutan yang diterima OJK pada tahun anggaran berjalan melebihi kebutuhan OJK untuk tahun anggaran berikutnya, maka kelebihan tersebut harus disetorkan ke kas negara. Hal ini tertera pada Pasal 3 ayat (3) Peraturan Pemerintah Nomor 11 Tahun 2011 tentang Pungutan oleh Otoritas Jasa Keuangan. Kelebihan atau yang biasa disebut surplus OJK tersebut termasuk kedalam APBN, tepatnya pada penghasilan bukan pajak lainnya (PNBP). Pada segmen PNBP Bagan Akun Standar (BAS), surplus OJK berada pada nomor akun 422212 dan termasuk kedalam pendapatan dari kekayaan negara yang dipisahkan (KND) lainnya. Hal ini menunjukkan bahwa kriteria ketiga terpenuhi.

Kriteria keempat dan terakhir adalah pembukuannya diperiksa oleh aparat pengawasan fungsional negara. Pada Pasal 38 ayat (8) UU OJK tertulis bahwa laporan keuangan tahunan OJK diaudit oleh Badan Pemeriksa Keuangan (BPK) atau kantor akuntan publik lainnya yang ditunjuk oleh BPK. Maka, kriteria keempat terpenuhi.

Dari empat kriteria yang telah disebutkan diatas, hanya satu kriteria yang tidak terpenuhi, yaitu pembiayaannya berasal dari APBN atau APBD. Tiga kriteria lainnya terpenuhi. Karena kriteria-kriteria tersebut bersifat kumulatif, yang artinya seluruh kriteria harus terpenuhi, maka dapat disimpulkan bahwa OJK tidak termasuk badan pemerintah yang dikecualikan dari pajak penghasilan sesuai pasal 2 ayat 3 UU PPh.

Mengingat bahwa OJK merupakan perpanjangan tangan dari Bank Indonesia (selanjutnya disingkat BI) dan BI pun merupakan subjek pajak, tidak seharusnya OJK mengajukan keringanan untuk dikecualikan dari subjek pajak. Dalam wawancara dengan Tatan 


\section{JURNALKU}

Volume 1 No. 1, Maret 2021

Jaka Tresnajaya selaku akademisi, Tatan menjelaskan bahwa perlakuan OJK tidak akan berbeda jauh dari BI. Lebih detail lagi, Beliau menjelaskan bahwa:

"Bank Indonesia tidak berorientasi pada profit, namun dia juga memiliki surplus atas usahanya. Maka itu, dia tidak beda jauh dengan OJK. BI kana ada uang dari penjamin, meminjamkan juga ke kliring, disitu ada surplusnya, ada di PPh surplus BI termasuk objek dan BI pun termasuk subjek walaupun tidak berorientasi pada profit." (Hasil wawancara Tatan Jaka Tresnajaya).

Selain hal tersebut, Beliau juga berpendapat bahwa BI lebih berhak jika ingin mengajukan pengecualian dari subjek pajak badan. Selain BI berhubungan dengan masyarakat baik secara langsung maupun tidak langsung, BI juga dinilai jauh lebih strategis dari OJK. Dengan demikian, dapat disimpulkan bahwa OJK merupakan subjek pajak dalam negeri yang berbentuk badan. Hal ini juga diperkuat dengan Surat Menteri Keuangan No. S1001/MK.03/2015 tanggal 10 Desember 2015 perihal status kewajiban perpajakan sebagaimana tertera dalam laporan keuangan OJK. Dalam surat tersebut ditegaskan bahwa OJK termasuk dalam pengertian subjek pajak badan dan tidak memenuhi kriteria badan pemerintah yang dikecualikan dari subjek pajak.

\section{Pengidentifikasian Surplus Otoritas Jasa Keuangan sebagai objek pajak penghasilan}

Setelah mengidentifikasi OJK sebagai subjek pajak badan dalam negeri, maka langkah selanjutnya adalah mengidentifikasi objek pajak yang dapat dikenakan terhadap OJK. Sebagaimana dijelaskan pada Pasal 4 ayat (1) UU PPh, yang dimaksud sebagai objek pajak adalah setiap tambahan penghasilan yang diterima oleh wajib pajak, baik yang dipakai untuk konsumsi atau untuk menambah kekayaan wajib pajak yang bersangkutan.

Untuk mendanai kegiatannya, OJK mengenakan pungutan terhadap pihak yang melakukan kegiatan di sektor jasa keuangan yang bersifat wajib. Pungutan tersebut merupakan penerimaan OJK dan akan digunakan untuk membiayai anggaran di tahun anggaran berikutnya. Seperti yang dijelaskan pada bab sebelumnya, pungutan tersebut terbagi menjadi dua jenis, yang pertama adalah biaya perizinan, pendaftaran pengesahan, persetujuan dan penelaahan atas rencana aksi korporasi dan yang kedua adalah biaya tahunan dalam rangka pengaturan, pemeriksaan, pengawasan, dan penelitian. Untuk biaya perizinan, pendaftaran, pengesahan, persetujuan dan penelaahan dibayarkan sebelum pengajuan proses tersebut dan dengan jumlah yang tertera pada lampiran PP Nomor 11 tahun 2014 tentang Pungutan OJK. Sedangkan untuk biaya tahunan wajib dibayarkan dalam 4 tahap selama setahun dan paling lambat dibayarkan pada tanggal 15 April, 15 Juli, 15 Oktober, dan 31 Desember pada tahun berjalan. Apabila pihak yang berkegiatan sektor jasa keuangan tersebut didapati sedang mengalami kesulitan keuangan, yaitu tidak mampu mempertahankan tingkat kesehatan atau berpotensi gagal, OJK dapat mengenakan pungutan sampai dengan $0 \%$. Pungutan $0 \%$ ini juga dapat diberlakukan kepada lembaga jasa keuangan yang pembentukannya oleh pemerintah atau didasarkan oleh undangundang.

Apabila jumlah pungutan tersebut melebihi kebutuhan OJK pada tahun anggaran berikutnya, maka kelebihan tersebut harus disetorkan ke kas negara. Maka, dapat dikatakan bahwa yang disetorkan ke kas negara tersebut merupakan tambahan penghasilan yang diterima oleh OJK karena kelebihan tersebut menjadi penghasilan bersih milik OJK. Hal ini sesuai dengan Pasal 4 ayat 1 UU PPh dimana disebutkan bahwa yang dimaksud sebagai penghasilan atau setiap tambahan kemampuan ekonomis yang diterima atau diperoleh wajib pajak merupakan objek pajak. Maka, dapat disimpulkan bahwa sisa manfaat pungutan atau surplus tersebut adalah objek pajak penghasilan.

Perihal pungutan yang merupakan objek pajak penghasilan juga diperkuat dengan Surat Direktur Jenderal Pajak Nomor S-487/PJ/2015 tanggal 2 Desember 2015 yang memperjelas bahwa penerimaan OJK yang berasal dari pungutan sektor jasa keuangan merupakan 


\section{JURNALKU}

Volume 1 No. 1, Maret 2021

penghasilan yang dikenakan pajak penghasilan sedangkan penerimaan OJK yang berasal dari APBN buka merupakan penghasilan yang dikenakan pajak penghasilan.

Mengingat bahwa OJK pernah menyatakan bahwa pungutan tersebut menurut OJK sama dengan pajak, perlu ditekankan bahwa pungutan tersebut tidak dapat disamakan dengan pajak. Hal ini disebabkan karena pungutan tersebut tidak berlaku secara umum dan tidak dilandasi oleh undang-undang. Mengacu pada Pasal 23A Undang-Undang Dasar Negara Indonesia Tahun 1945, setiap pajak dan pungutan lainnya yang bersifat memaksa diatur dengan undang-undang, bukan dengan peraturan pemerintah. Sedangkan, pungutan OJK hadir dengan berlandaskan PP Nomor 11 Tahun 2014. Pungutan ini dapat dipersamakan dengan pungutan yang dilakukan oleh kementerian atau lembaga lainnya jika OJK masih dibiayai oleh APBN. Namun, karena setelah tahun 2016 pembiayaan OJK sepenuhnya berasal dari Pungutan, secara tidak langsung OJK sudah menjadi kekayaan negara yang dipisahkan sehingga pungutan tersebut merupakan objek pajak penghasilan.

Tatan Jaka Tresnajaya selaku akademisi pun memberikan pendapat bahwa iuran (pungutan) tersebut merupakan objek pajak. Selain itu, beliau berpendapat juga bahwa pungutan ersebut tidak dapat disamakan dengan pajak yang selama ini disetorkan ke DJP. Beliau juga menjelaskan bahwa:

"Iuran itu bukan untuk setiap orang, kan? Melainkan setiap lembaga yang diawasinya aja, bukan? Berarti gak bisa (disamakan dengan pajak). Kalau pajak kan semua, baik badan ataupun orang. Misalnya, untuk perusahaan dalam bidang plastik. Dia dikasih pungutan khusus untuk limbah plastik. Tidak berbeda kan dengan ini, khusus untuk lembaga yang bergerak di jasa keuangan yang dia awasi aja. Tidak berlaku umum. Nanti kalau pungutan OJK jadi pajak, nanti pungutan kementrian lain juga jadi pajak. Kalau memang sudah dianggap pajak, nanti pungutan tersebut jadi kredit pajak? Nanti banyak pertentangannya." (Hasil wawancara Tatan Jaka Tresnajaya).

Selain itu, Rachmad Utomo, sesama akademi PKN STAN menilai, akan sulit apabila pungutan tersebut ingin dianggap sebagai pajak. Secara lengkap, beliau menjelaskan bahwa:

"Kalau dia menganggap apa yang dia pungut dari member (lembaga jasa keuangan yang terdaftar di OJK) dan pendapatannya tersebut dianggap sebagai pajak ya susah. Karena pajak itu harus dibayar ke kas negara. Contohnya saja, pun tidak pajak, misalnya PNBP, itu ada undang-undangnya sendiri ada PP nya sendiri bahwa setiap kementerian itu boleh memungut sesuatu ke kas negara. Nanti, setelah masuk ke kas negara, dituangkan lagi ke APBN, anggaran ke masing-masing K/L setelah sebelumnya masuk ke pusat dulu, itu kalau OJK mau seperti kayak pajak, ya namanya PNBP. Kalau PNBP mungkin lebih cepat karena tidak harus undang-undang. Tapi perjalannnya panjang banget." (Hasil wawancara Rachmad Utomo).

Dari kedua pendapat tersebut dapat ditarik kesimpulan bahwa meskipun pungutan OJK disetorkan ke kas negara, bukan berarti pungutan ini dipersamakan dengan pajak karena tidak berlaku secara umum, tepatnya hanya bagi lembaga yang diawasi oleh OJK, yaitu lembaga yang bergerak di bidang jasa keuangan. Walaupun bukan pajak, PNBP mungkin akan lebih tepat mengingat OJK merupakan lembaga yang dipisahkan. Namun hal tersebut juga akan melalui proses yang sangat panjang. Maka, pungutan tersebut merupakan objek pajak dan tidak bisa disamakan dengan pajak.

\section{Pembahasan pajak penghasilan badan atas Otoritas Jasa Keuangan}

Kewajiban perpajakan timbul ketika persyaratan subjektif dan persyaratan objektif telah terpenuhi oleh semua wajib pajak sesuai dengan Pasal 2 ayat (1) UU KUP. Yang dimaksud dengan persyaratan subjektif adalah persyaratan yang sesuai dengan ketentuan subjek pajak dalam UU PPh. Sedangkan yang dimaksud dengan persyaratan objektif adalah persyaratan bagi 


\section{JURNALKU}

Volume 1 No. 1, Maret 2021

subjek pajak yang menerima penghasilan atau diwajibkan untuk melakukan pemotongan/ pemungutan sesuai dengan UU PPh.

OJK sepenuhnya dibiayai oleh APBN sejak 2011 hingga 2013. Pada 2014, terbit Peraturan Pemerintah Nomor 11 Tahun 2014 tentang Pungutan OJK yang menandakan sejak tahun tersebut OJK tidak dibiayai sepenuhnya oleh APBN. Sejak saat OJK menerima penghasilan lain selain APBN, maka OJK termasuk ke dalam subjek pajak sebagaimana pembahasan sebelumnya mengenai status OJK sebagai subjek pajak. Hal tersebut menandakan OJK telah memenuhi persyaratan subjektif dalam UU PPh.

Sehubungan dengan persyaratan objektif, OJK menerima penghasilan dari pungutan dari pihak yang melakukan kegiatan di sektor jasa keuangan sesuai PP 11 tahun 2014 sebagaimana yang sudah dijelaskan di pembahasan sebelumnya. Berdasarkan laporan keuangan OJK tahun 2014, OJK juga pernah menerima Surat Keterangan Terdaftar Direktorat Jenderal Pajak Nomor PEM-00011/WPJ.06/KP.1403/2013 yang menerangkan bahwa OJK untuk sementara berstatus sebagai Wajib Pungut Pajak dengan pertimbangan OJK sepenuhnya dibiayai dari APBN. Dari penjelasan-penjelasan tersebut maka dapat ditarik kesimpulan bahwa OJK telah memenuhi persyaratan objektif dalam UU PPh yaitu menerima penghasilan atau melakukan pemungutan/ pemotongan penghasilan.

Karena OJK telah memenuhi persyaratan subjektif dan objektif sesuai dengan Pasal 2 ayat (1) UU KUP pada tahun 2014, maka sejak tahun tersebut telah timbul kewajiban perpajakan yang harus dilakukan oleh OJK, yang diantaranya adalah melakukan pelaporan Surat Pemberitahuan Tahunan dan membayar pajak penghasilan badan setiap tahunnya.

Terdapat pengecualian pada tahun 2014 dimana OJK tidak membayar pajak penghasilan tahun tersebut. Hal ini diakibatkan karena pungutan tahun 2014 akan digunakan untuk membiayai tahun anggaran 2015, sehingga pungutan pada tahun tersebut belum merupakan tambahan kemampuan ekonomis. Yang dimaksud tambahan kemampuan ekonomis yang dimiliki OJK adalah jumlah kelebihan pungutan yang telah digunakan untuk membiayai tahun anggaran berikutnya. Hal ini mengakibatkan jumlah kelebihan pungutan atau surplus tersebut baru dapat diketahui jumlahnya pada tahun 2015. Maka, dapat ditarik kesimpulan bahwa surplus tersebut akan menjadi penghasilan kena pajak di tahun 2015 dan pada tahun 2014 tidak terdapat pajak penghasilan terutang oleh OJK.

Mengenai perhitungan surplus OJK, dasar yang digunaan oleh OJK dalam menentukan surplus tersebut bukan anggaran kebutuhan yang ditetapkan untuk tahun anggaran berikutnya, melainkan realisasi anggaran kebutuhan tahun anggaran berikutnya. Sebagai contoh, apabila pungutan tahun 2017 sebesar Rp3.000.000.000,00, anggaran kebutuhan yang ditetapkan untuk tahun 2018 sebesar Rp2.500.000.000,00, dan realisasi anggaran kebutuhan tahun 2018 sebesar Rp2.200.000.000,00, maka yang menjadi dasar surplus tersebut adalah realisasi anggaran kebutuhan tahun 2018 sehingga surplus yang diakui yaitu sebesar Rp800.000.000,00. Surplus tersebut harus disetorkan oleh OJK ke kas negara setelah mengetahui realisasi anggaran kebutuhan tahun 2018.

Selain itu juga, jumlah pungutan yang digunakan dalam perhitungan surplus tersebut adalah jumlah kas yang diterima oleh OJK. Sebagai contoh, jumlah tagihan pungutan yang belum dibayar oleh pihak lain pada tahun 2017 sebesar Rp3.000.000.000,00 dan jumlah kas yang diterima OJK dari pungutan pada tahun 2017 sebesar Rp2.500.000.000,00. Maka, jumlah pungutan OJK yang akan menjadi dasar perhitungan surplus penghasilan adalah sebesar Rp2.500.000.000,00.

Selama ini, perhitungan pajak penghasilan terutang OJK menggunakan skema $\mathrm{PPh}$ Badan pada umunya, yaitu 25\% sesuai dengan Pasal 17 ayat (2c) UU No. 36 Tahun 2008 Tentang Pajak Penghasilan. Apabila OJK hendak mengajukan penggunaan tarif final sebagai kemudahan dalam pemenuhan kewajiban perpajakannya, hal tersebut dirasa kurang tepat. 


\section{JURNALKU}

Volume 1 No. 1, Maret 2021

Menurut Hanik Muamarah selaku akademisi, kewajiban perpajakan OJK sudah selayaknya mengikuti ketentuan wajib pajak badan pada umumnya. Beliau menilai bahwa mekanisme yang ada sekarang sudah cukup memadai jika dilihat dari karakteristik OJK tersebut. Beliau juga menambahkan bahwa ada baiknya jika dilakukan benchmarking dengan lembaga sejenis OJK di luar negeri, misalnya U.S. Securities and Exchange Commision yang merupakan lembaga pengawas sekuritas milik Amerika Serikat. (Hasil wawancara Hanik Muamarah, 23 Mei 2019).

Sejalan dengan pendapat tersebut, Rachmad Utomo sebagai sesama akademisi juga menilai bahwa pengenaan tarif final akan menyebabkan ketidakadilan bagi yang lain. Beliau menjelaskan secara lengkap bahwa:

"Kalau dia difinalkan atau tarifnya beda, itu akan membuat ketidak adilan bagi yang lain. Contohnya saja yang kena PNBP dengan tarif yang lebih tinggi. Aspek ketidak adilan akan muncul. Itu yang pasti, ada objek pajak. Jika mau di finalkan atau dipermudah harus dihitung seberapa besar dampak ketidak adilan bagi pelaku usaha yang lain atau entitas yang lain." (Hasil wawancara Rachmad Utomo).

Dapat ditarik kesimpulan dari pendapat-pendapat tersebut bahwa penggunaan tarif $\mathrm{PPh}$ badan pada umumnya yaitu $25 \%$ sesuai UU PPh sudah tepat. Apabila OJK dikenakan tarif final atau khusus, maka akan timbul ketidak adilan bagi pelaku usaha sejenis.

\section{PENUTUP}

Otoritas Jasa Keuangan termasuk kedalam subjek pajak penghasilan berbentuk badan, karena OJK tidak memenuhi persyaratan akumulatif dalam Pasal 2 ayat (3) huruf b UU PPh mengenai badan yang dikecualikan dari subjek pajak badan. Dalam penetapan subjek pajak badan ini, OJK dapat dimiripkan dengan Bank Indonesia dimana keduanya memiliki penghasilan yang sejenis yaitu berupa surplus atau sisa manfaat pungutan. Hal ini juga diperkuat dengan adanya Surat Menteri Keuangan No. S-1001/MK.03/2015 tentang status kewajiban perpajakan OJK dimana dalam surat tersebut ditegaskan bahwa OJK merupakan subjek pajak badan.

Sisa manfaat pungutan dari lembaga swasta yang berkegiatan di bidang jasa keuangan merupakan objek pajak penghasilan OJK, karena surplus tersebut merupakan tambahan penghasilan bagi OJK. Hal ini diperkuat dengan adanya Surat Direktur Jenderal Pajak Nomor S-487/PJ/2015 yang memperjelas bahwa sisa pungutan tersebut merupakan objek pajak penghasilan OJK. Pungutan OJK juga tidak dapat dipersamakan dengan pajak karena pungutan tersebut hanya berlaku kepada lembaga yang berkegiatan di sektor jasa keuangan dan tidak berlaku umum.

OJK telah memenuhi persyaratan subjektif dan objektif sesuai dengan UU PPh Pasal 2 ayat (1) UU KUP, sehingga timbul kewajiban perpajakan berupa pembayaran $\mathrm{PPh}$ dan pelaporan SPT. Dalam melakukan perhitungan $\mathrm{PPh}$ terutang, OJK akan lebih tepat jika menggunakan tarif PPh badan 25\% sesuai UU PPh. Jika OJK mengajukan penggunaan tarif final atau norma, akan muncul ketidak adilan bagi pelaku usaha sejenis.

\section{DAFTAR PUSTAKA}

Judisseno, Rimsky K. (1997). Perpajakan (Edisi Revisi). Jakarta: Gramedia Pustaka Utama. Mardiasmo. (2011). Perpajakan Edisi Revisi 2011. Yogyakarta : Penerbit Andi.

Rahayu, S. K. (2010). Perpajakan Indonesia: Konsep dan Aspek Formal. Yogyakarta: Graha Ilmu.

Waluyo. (2011). Perpajakan Indonesia. Jakarta: Salemba Empat.

Wijaya, S. (2017). Analisis Revaluasi aktiva tetap di PT Indonesia Power. Jurnal Pajak Indonesia (Indonesian Tax Journal), 1(1), 106-117. 


\section{JURNALKU}

Volume 1 No. 1, Maret 2021

Wijaya, S., \& Nirvana, A. P. (2021). Pajak Pertambahan Nilai Perdagangan Melalui Sistem Elektronik (Studi Kasus PT Shopee Internasional Indonesia). Bilancia: Jurnal Ilmiah Akuntansi, 5(3), 245-256.

Wijaya, S., \& Safira, A. F. (2021). Pajak Penghasilan Atas Anak Angkat Yang Berpenghasilan. Owner: Riset dan Jurnal Akuntansi, 5(2), 396-406.

Wijaya, S., \& Utamawati, H. (2018). Pajak Penghasilan dari Ekonomi Digital atas CrossBoarder Transaction. Jurnal Online Insan Akuntan, 3(2), 135-148.

Zain, M. 2008. Manajemen Perpajakan. Jakarta: Salemba Empat.

Peraturan Pemerintah Nomor 11 Tahun 2014 tentang Pungutan oleh Otoritas Jasa Keuangan.

Undang-Undang Dasar Negara Republik Indonesia Tahun 1945.

Undang-Undang Nomor 21 Tahun 2011 tentang Otoritas Jasa Keuangan.

Undang-Undang Nomor 28 Tahun 2007 tentang Perubahan Ketiga atas Undang-Undang Nomor 6 Tahun 1983 tentang Ketentuan Umum dan Tata Cara Perpajakan

Undang-Undang Nomor 36 Tahun 2008 tentang Perubahan Keempat atas Undang-Undang Nomor 7 Tahun 1983 tentang Pajak Penghasilan. 